\title{
ESTIMATION OF SOIL ORGANIC MATTER ON PADDY FIELD USING REMOTE SENSING METHOD
}

\author{
Luthfan Nur Habibi ${ }^{1 *}$, Komariah ${ }^{2}$, Dwi Priyo Ariyanto ${ }^{2}$, Jauhari Syamsiyah' ${ }^{2}$, and Takashi S.T. Tanaka ${ }^{3}$ \\ ${ }^{1}$ Undergraduate student, Department of Soil Science, Faculty of Agriculture, Sebelas Maret \\ University, Surakarta 57126, Indonesia \\ ${ }^{2}$ Department of Soil Science, Faculty of Agriculture, Sebelas Maret University \\ ${ }^{3}$ Faculty of Applied Biological Sciences, Gifu University, Japan
}

Submitted: 2019-11-03 Accepted: 2019-12-06

\begin{abstract}
Soil organic matter (SOM) is one of the important parameters in agriculture management, thus estimating its distribution on the land will be essential. Remote sensing can be utilized to map the SOM distribution in the large-scale area. The objective of this research was to determine the estimation of SOM distribution on the paddy field in Sukoharjo Regency, Indonesia using Landsat 8 $\mathrm{OLI}$ imagery. The sampling points were determined by purposive sampling based on an overlay of land use classification map of paddy field, NDSI (Normalized Difference Soil Index) map, and soil type map. The analysis method was used simple linear regression (SLR) and multiple linear regression (MLR) between SOM content and a digital number of Landsat $8 \mathrm{OLI}$ imagery. The SLR analysis resulted that all band except band 1 and 5 of Landsat $8 \mathrm{OLI}$ Imagery have the capability to estimating SOM. The MLR model based on best subset analysis resulted in the combination of bands 3, 4, 6, and 7 was the best model for estimating SOM distribution $\left(R^{2}=0.399\right)$. The MLR model was used to create SOM distribution map on paddy field in Sukoharjo Regency and resulted in the SOM range of the area is distributed from very low $(<1 \%)$ to moderate $(2.1-4.2 \%)$ with the largest area was on low level (1$2 \%$ ) about 11,028 ha. The result indicates that Landsat $8 \mathrm{OLI}$ Imagery could be used for mapping the SOM distribution.
\end{abstract}

Keywords: Landsat 8 OLI, NDSI, PCA, Precision agriculture, Regression

How to Cite: Habibi, L. N., Komariah, Ariyanto, D.P., Syamsiyah, J., and Tanaka, T.S.T. Sains Tanah Journal of Soil Science and Agroclimatology, 16(2): 159-168 (doi: 10.20961/stjssa.v15i2.35395)

Permalink/DOI: http://dx.doi.org/10.20961/stjssa.v16i2.35395

\section{INTRODUCTION}

The majority of the agriculture sector in Indonesia still cultivating wetland (lowlandirrigated) paddy fields owned by small-holder or individual farmers (Agus, 2011; Syuaib, 2016). The application of chemical fertilizer had increased after the "Green Revolution" program established in the late 1960s that

\footnotetext{
* Corresponding Author :

Email: noerhabibii@gmail.com
}

caused the increase of fertilizer consumption up to five-fold to increase crop productivity (Komatsuzaki \& Syuaib, 2010). It might result in unbalanced soil nutrients and soil fertility decline to disturb plant growth. The decrease of soil organic matter (SOM) content is an indication of the decreasing soil fertility status (Supriyadi et al., 2014). SOM has an important role in agriculture soil especially for helping soil fertility sustainability, soil and water quality conservation, maintaining the nutrient 
and biological cycles inside the soil, and also affecting plant growth directly and indirectly (Komatsuzaki \& Syuaib, 2010; Lee et al., 2009). In general, the SOM content in soil can be maintained if crop residues are returned after harvesting and supplemented soil with nutrient inputs (Hutchinson et al., 2007). However, in conventional rice cultivation burning crop residue is a common practice in the field (Komatsuzaki \& Ohta, 2007). The substitution of land-cultivation practices with sustainable agriculture systems is necessary to reduce the level of land degradation due to intensive agriculture.

Precision agriculture is a management system of soil and crop that accesses the spatial variability data of soil properties to improve crop productivity by measuring the input of fertilizer, seedling, and other cultivation practices based on the within-field obtained information (Kim et al., 2009). The approximate distribution of organic matter in the soil can be used as information in precision agriculture practices on farmland. Estimate distribution of SOM accurately is very important, because SOM is one of the soil properties that play a role in the availability of soil nutrients (Wu et al., 2009). Analysis of SOM distribution can be carried out by the conventional method through field survey and intensive sampling, but it required time and cost that makes this practice seems impractical (Kim et al., 2009). Another alternative method that can be used to estimate the distribution of SOM is through remote sensing technology. Remote sensing has been widely used as a tool for estimating the distribution of SOM (Chen et al., 2000; Nocita et al., 2013), primarily using Landsat imagery (Rahmati et al., 2016; Ahmed \& Iqbal, 2014; Sukojo \& Wahono, 2002; Wu et al., 2009). Remote sensing can increase the speed of monitoring soil properties across the field and reducing the fieldwork significantly because with it we can easily monitoring without directly survey the field (Ahmed \& Iqbal, 2014).

Landsat imagery is multispectral imagery released by the United States Geological Survey (USGS) and records the Earth's surface periodically (every 16 days) (Department of the Interior USGS, 2015). The multispectral band sensor of Landsat imagery can be used to studying soil attributes by the reflectance spectra as long as the soil is fully exposed and not covered by dense plants or canopy trees (Ahmed \& Iqbal, 2014). Previous research is still using long-standing Landsat TM and ETM+ (Rahmati et al., 2016; Ahmed \& Iqbal, 2014; Sukojo \& Wahono, 2002; Wu et al., 2009). The use of Landsat 8 OLI (Operational Land Imager) which has a new sensor and free from sensor damage as Landsat 7 ETM+ (SLC OFF) have, is expected to allow to estimate the SOM more accurately. Similar research about monitoring soil properties especially SOM with satellite imagery is hard to find in Indonesia, even though this research is crucial since Indonesia holds a large area of agriculture field and needs to develop a better agriculture system in the future. Therefore, the purpose of this research is to estimate the distribution of soil organic matter by using Landsat $8 \mathrm{OLI}$ imagery in a paddy field at Sukoharjo Regency, Indonesia.

\section{MATERIALS AND METHODS}

The study area is Sukoharjo Regency, Central Java, Indonesia. The study area lays at $7^{\circ} 32^{\prime} 17^{\prime \prime}-7^{\circ} 49^{\prime} 32^{\prime \prime}$ South and $110^{\circ} 57^{\prime}$ $33.7^{\prime \prime}-110^{\circ} 42^{\prime} 6.79^{\prime \prime}$ East with a total area of 46,666 ha. The landscape of the study area is dominated by the plains, with some hilly areas in the east and south. Paddy field is located in a plain area and has a total area of 28,296 ha. The study area is classified as a tropical monsoon climate (Am) according to Koppen 
classification and B2 climate type according to Oldeman with two seasons in one year, i.e. rainy and dry season. The average temperature in this region ranges from $23-$ $34{ }^{\circ} \mathrm{C}$ with an average annual rainfall of 1,766 $\mathrm{mm}$ in the past 5 years (BPS Statistic of Sukoharjo Regency, 2015). The main agriculture cultivation in this region is irrigated and upland paddy fields.

A total of 28 soil samples $(0-20 \mathrm{~cm})$ were taken from paddy fields spread in the study area from March to April 2017. Soil samples were taken with purposive sampling based on the land unit. The content of SOM was measured by the Walkey and Black method (Balai Penelitian Tanah, 2005) at Chemical and Soil Fertility Laboratory, Faculty of Agriculture, Sebelas Maret University. The land unit was from an overlay of land use classification map, soil type map of the study area, and Normalized Difference Soil Index (NDSI) based on Landsat $8 \mathrm{OLI}$ Imagery. The Landsat 8 OLI Imagery we used in this research was recorded on October $10^{\text {th }}, 2014$. Land use classification map and soil type map were used to determine all samples taken from paddy fields and all types of soil available in the study area. The land use classification map was based on the analysis of Landsat $8 \mathrm{OLI}$ Imagery using the Support Vector Machine method to derive the Land Use Land Cover (LULC) of the research area (Al-doski et al., 2013; Singh et al., 2014). Google Earth imagery also used to ensure the land use of the study area did not have any major change from 2014 to 2017.

The NDSI imagery which was from image interpretation and classification based on Band 3 and 7 of Landsat 8 OLI Imagery. The NDSI was used to identify open land or minimal vegetation cover so the image recorded the soil condition. Classification of NDSI as follows: Positive NDSI values (0.0 - 0.3) were dominant in the study area, which indicates most of the land is in a fallow state when the imagery is recorded. In addition, lover values of NDVI (below 0.0 ) are classified as vegetation or water surface, and higher NDVI values (over 0.3 ) can be classified as concrete surface (Deng et al., 2015).

DN of Landsat $8 \mathrm{OLI}$ imagery was used as auxiliary data in estimation modeling to predict the distribution of soil organic matter in the study area. In this study, we took DN sampling from 6 bands of Landsat 8 OLI imagery, i.e. Band 2 - Blue $(0.43-0.45 \mu \mathrm{m})$, Band 3 - Green (0.53-0.59 $\mu \mathrm{m})$, Band 4 - Red (0.64-0.67 $\mu \mathrm{m})$, Band $5-\mathrm{NIR} /$ Near InfraRed (0.85-1.88 $\mu \mathrm{m})$, Band 6 - SWIR 1/ Short-wave InfraRed 1 (1.56-1.66 $\mu \mathrm{m})$, and Band 7 - SWIR 2/ Short-wave InfraRed $2(2.10-2.30 \mu \mathrm{m})$. Estimation of soil organic matter distribution was performed by using the resulting model from simple linear regression (SLR) analysis and multiple linear regression (MLR) analysis.

The analysis of SLR and MLR was performed to build a SOM prediction model based on data from 28 soil samples as the criterion variable with the DN sampling data from Landsat $8 \mathrm{OLI}$ imagery as the predictor variable. The purpose of SLR analysis is to know the relationships and potential of each Band of Landsat $8 \mathrm{OLI}$ imagery in predicting SOM. Meanwhile, MLR analysis is performed to obtain all possible models of $\mathrm{DN}$ band Landsat to predict the SOM by using the best subset analysis. Best subset analysis is one method for selecting predictor variables that will be included in the regression analysis so that all possible sub-models will be obtained and the most optimal models can be selected to be used (Gatu \& Kontoghiorghes, 2006). The best subset analysis will form the best combination of DN Landsat 8 imagery to estimate the SOM with the criteria of the model having high $R^{2}$ (R-sq) and Adjusted $R^{2}$ (Adj R-sq), low $S$, and Mallows' $C p$ value close to the number of predictor variable and the 
constant. All of the statistical analysis is performed using Minitab 17 software (Minitab Inc., USA).

MLR analysis using remote sensing data Landsat imagery often appear multicollinearity in the model. Multicollinearity is a condition where several predictor variables in multiple regression analysis have a high correlation (Sunaryo \& Siagian, 2011). The multicollinearity test was performed on the model-based by best subset analysis and multicollinearity symptoms indicated by the high variance inflation factor (VIF) value of the predictor variable. Multicollinearity symptoms are common in Landsat imagery data (Sukojo \& Wahono, 2002). Multicollinearity greatly affects the model's ability to estimate the soil organic matter content because the model will be unstable and unadjustable. Principal component analysis (PCA) was used to eliminate multicollinearity in the model. Several studies (Idris et al., 2014; Sukojo \& Wahono, 2002) suggest that PCA can be used to reduce multicollinearity symptoms in multiple regression analyses using DN data of Landsat imagery. Calculation of the estimated area of SOM in the study area was performed using the ENVI 5.1 (Harris Geospatial Solutions, USA) by applying the established model into Band Math calculation. The distribution of SOM maps was created in ArcGIS 10.1 (Esri, USA) software. All statistical analyses were considered significant at $P<$ 0.05 . The accuracy of the models was tested by using the standard error of estimate (SE) analysis as presented in Equation [1].
$\mathrm{SE}=\sqrt{\frac{\Sigma\left(\mathrm{y}^{\prime}-y\right)^{2}}{n-1}}$

where:

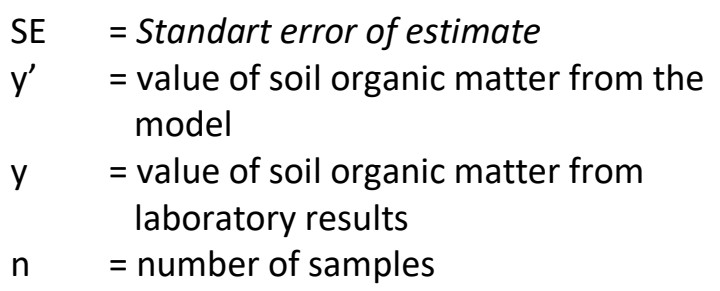

\section{RESULTS}

Table 1 are shown the correlation analysis between DN data of Landsat 8 imagery (Bands 2-7) as predictor variables and SOM content as criterion variables obtained from all sample points were taken in the research area and satellite imagery. The value of DN of Band 7 has the strongest correlation with SOM with a correlation coefficient $(r)$ of 0.558 and P-value of 0.002 (significant), followed by Band 2, 3, 4, and 6 respectively which also had a significant correlation to SOM. Different results were obtained from the Band 5 variable which has a correlation value of -0.288 with a P-value of 0.138 which means that this variable has no significant correlation on SOM.

The SOM estimation model by SLR analysis was used field data of SOM as the criterion variable and DN Landsat imagery that significantly correlated with SOM as the predictor variable. The results of the analysis (Tabel 2) indicated that the best model was the model with variable Band 7 with a coefficient of determination $\left(R^{2}\right)$ value of 0.310 .

Table 1. Pearson correlation between soil organic matter (SOM) content and digital number (DN) of Landsat 8 OLI imagery.

\begin{tabular}{ccccccc}
\hline & Band 2 & Band 3 & Band 4 & Band 5 & Band 6 & Band 7 \\
\hline SOM & -0.556 & -0.553 & -0.543 & $-0.288^{\text {ns }}$ & -0.509 & -0.558 \\
P-Value & 0.002 & 0.002 & 0.003 & 0.138 & 0.006 & 0.002 \\
\hline
\end{tabular}

Remarks: All correlation coefficient listed are significant (except Band 5) at $\mathrm{P}<0.05$ level, ns: non-significant 
Table 2. Linear regression model of soil organic matter content (SOM) and digital number (DN) of Landsat 8 OLI imagery.

\begin{tabular}{cccc}
\hline Band & Model & $\mathbf{R}^{2}$ & SE \\
\hline B2 & SOM $=5.85-29.02 \mathrm{~B} 2$ & 0.309 & 0.49 \\
B3 & SOM $=4.95-23.35 \mathrm{~B} 3$ & 0.305 & 0.48 \\
B4 & SOM $=3.60-12.61 \mathrm{~B} 4$ & 0.294 & 0.48 \\
B6 & SOM $=3.46-6.33 \mathrm{~B} 6$ & 0.259 & 0.46 \\
B7 & SOM $=3.30-8.91 \mathrm{~B} 7$ & 0.310 & 0.44 \\
\hline
\end{tabular}

Remarks: $\mathrm{B} 2=\mathrm{Band} 2 ; \mathrm{B} 3=\mathrm{Band} 3 ; \mathrm{B} 4=\mathrm{Band} 4 ; \mathrm{B} 6=$ Band 6; $\mathrm{B} 7=$ Band 7; $\mathrm{SE}=$ Standart Error of Estimate

The model with Band 6 variable has the lowest $R^{2}$ value of 0.259 . The coefficient of determination can reflect how strong the influence of the dependent variable on the independent variable, and it is divided into 5 categories based on the strength of the relationship (Ratner, 2009). The coefficient of determination $\left(R^{2}\right)$ from the resulting models has low-value categories ranging from 0.259 0.310 . SE value was generated based on Equation [1] in the estimation model is ranging from 0.44 to 0.49 with the lowest coming from the Band 7 model.

Table 3 shows the result of the combinations of MLR analysis that was based on the best subset analysis in the Minitab 17 application. Through this analysis, a total of 9 combinations with several band Landsat 8 OLI Imagery variable models can be used to estimate SOM in the research area. The best model of best subset analysis was obtained with the combination of 4 predictor variables including Band 3, 4, 6, and 7, and it produced an $R^{2}$ value of $39.9, R^{2}$ (adj) of $29.5, S$ value of 0.51282 , and Mallows' CP 4.0 which are valued according to the criteria. Based on the combination of variables from the Best Subset analysis the model is obtained by Equation [2]. $\mathrm{SOM}=3.79-32.5 \mathrm{~B} 3+29.3 \mathrm{~B} 4+20.7 \mathrm{~B} 6-$

$$
43.2 \mathrm{~B} 7
$$

Table 3. Results of the Best Subset analysis of digital number (DN) Landsat 8 OLI imagery.

\begin{tabular}{|c|c|c|c|c|c|c|c|c|c|}
\hline \multirow{2}{*}{ Vars } & \multirow{2}{*}{$\mathbf{R}^{2}$} & \multirow{2}{*}{$R^{2}$ (adj) } & \multirow{2}{*}{$\begin{array}{c}\text { Mallows } \\
\text { Cp }\end{array}$} & \multirow{2}{*}{$S$} & \multicolumn{5}{|c|}{ Band } \\
\hline & & & & & 2 & 3 & 4 & 6 & 7 \\
\hline 1 & 0.311 & 0.284 & 1.3 & 0.51657 & & & & & $x$ \\
\hline 1 & 0.309 & 0.283 & 1.3 & 0.51726 & $x$ & & & & \\
\hline 2 & 0.359 & 0.308 & 1.5 & 0.50810 & & & & $x$ & $x$ \\
\hline 2 & 0,321 & 0.266 & 2.9 & 0.52307 & $x$ & & & & $x$ \\
\hline 3 & 0,368 & 0.289 & 3.2 & 0.51476 & & $x$ & & $x$ & $x$ \\
\hline 3 & 0.367 & 0.287 & 3.2 & 0.51547 & & & $x$ & $x$ & $x$ \\
\hline 4 & 0.399 & 0.295 & 4.0 & 0.51282 & & $x$ & $x$ & $x$ & $x$ \\
\hline 4 & 0.384 & 0.277 & 4.6 & 0.51928 & $x$ & & $x$ & $x$ & $x$ \\
\hline 5 & 0.400 & 0.264 & 6.0 & 0.52395 & $x$ & $X$ & $x$ & $x$ & $x$ \\
\hline
\end{tabular}

Remarks: $X=$ Variable included in the model; $S=$ Square root of the mean square error (MSE)

Table 4. Principal Component Analysis (PCA) of 4 predictor variables* MLR Model.

\begin{tabular}{lcccc}
\hline & PC1 & PC2 & PC3 & PC4 \\
\hline Eigenvalue & 3.9017 & 0.0594 & 0.0318 & 0.0071 \\
Proportion & 0.975 & 0.015 & 0.008 & 0.002 \\
Cumulative & 0.975 & 0.990 & 0.998 & 1.000 \\
\hline
\end{tabular}

Remarks: * Predictor variable= Band 3, Band 4, Band 6, Band 7 
The coefficient of determination $\left(R^{2}\right)$ of the resulting model has a better result than the SLR analysis $\left(R^{2}=0.399\right)$. Hence, the model cannot be used to estimate SOM yet and must be followed by PCA analysis to clear the multicollinearity that appears in the model. The analysis of PCA was performed on 4 predictor variables of model-based by Equation [2] resulted in 4 main components (PC) as presented in Table 4. It shows $97.5 \%$ of data can be accommodated by PC1 (proportion $=0.975$ ) which means that PC1 can be used to analyze SOM. This is also supported by the highest eigenvalue (3.9017). Therefore, a new MLR model is established based on the PCA analysis and presented as Equation [3].

$\mathrm{SOM}=3.87-5.81 \mathrm{~B} 3-3.23 \mathrm{~B} 4-1.72 \mathrm{~B} 6-$ $2.22 \mathrm{~B} 7$

This model has the same capability to estimate SOM, which was done by Equation [2]. Both

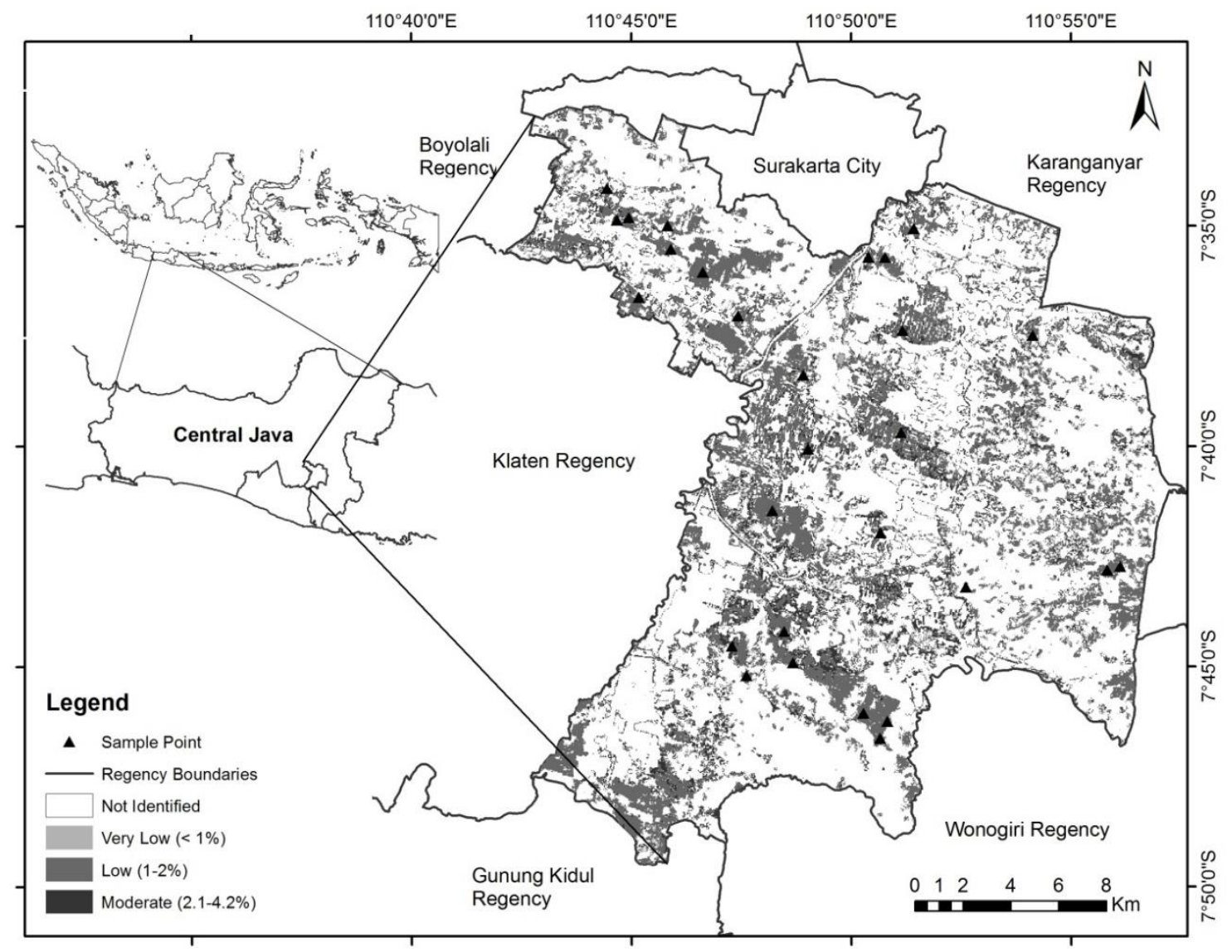

Figure 1. The map of soil organic matter (SOM) distribution at Sukoharjo Regency, Indonesia equations have the same $R^{2}$ value but Equation [3] has no multicollinearity of the predictors. SE value was generated based on Equation [1] in the estimation model about 0.46 .

Table 5 is presented the extent of SOM distribution in the study area based on the estimation results from the SLR models as shown in Table 2. Models using visible light bands (Band 2, 3, and 4) and Short-wave InfraRed/SWIR bands (Band 6 and Band 7) produced an estimation of SOM from very low $(<1 \%)$ to moderate $(2.1-4.2 \%)$. Each model resulted from SLR models were produced very diverse and different extents each other. For instance, invisible light bands the area was to be dominant at low-level and moderate-level content in a balanced percentage. Whereas by the short-wave InfraRed band, SOM was found predominantly in low-level content. 
Habibi et al. / SAINS TANAH - Journal of Soil Science and Agroclimatology, 16(2), 2019, 165

Table 5. Soil organic matter (SOM) distribution by single linear regression (SLR) models in the study area

\begin{tabular}{ccccc}
\hline \multirow{2}{*}{$\begin{array}{c}\text { Model } \\
\text { Band }\end{array}$} & $\begin{array}{c}\text { Very low-level } \\
(<\mathbf{1 \% )}\end{array}$ & $\begin{array}{c}\text { Low-level } \\
\mathbf{( 1 - 2 \% )}\end{array}$ & $\begin{array}{c}\text { Moderate level } \\
\mathbf{( 2 . 1 - 4 . 2 \% )}\end{array}$ & Total (Ha) \\
\cline { 2 - 4 } & 118 & 9,001 & 8,783 & \\
\hline B2 & 117 & 9,412 & 8,358 & 17,901 \\
B3 & 78 & 10,231 & 7,601 & 17,887 \\
B4 & 1 & 13,247 & 4,588 & 17,836 \\
B6 & 15 & 12,936 & 4,965 & 17,916 \\
\hline
\end{tabular}

Remarks: $\mathrm{B} 2=$ Band 2; $\mathrm{B} 3=$ Band 3; $\mathrm{B} 4=$ Band 4; $\mathrm{B} 6=\mathrm{Band} 6 ; \mathrm{B} 7=\mathrm{Band} 7$

Table 6. SOM distribution by MLR model in study area.

\begin{tabular}{|c|c|c|c|c|}
\hline \multirow{2}{*}{$\begin{array}{c}\text { Band } \\
\text { Combination }\end{array}$} & \multicolumn{3}{|c|}{ The distribution area of SOM (ha) } & \multirow[b]{2}{*}{ Total (Ha) } \\
\hline & $\begin{array}{c}\text { Very low-level } \\
(<1 \%)\end{array}$ & $\begin{array}{c}\text { Low-level } \\
(1-2 \%)\end{array}$ & $\begin{array}{c}\text { Moderate level } \\
(2.1-4.2 \%)\end{array}$ & \\
\hline $\mathrm{B} 3, \mathrm{~B} 4, \mathrm{~B} 6, \mathrm{~B} 7$ & 70 & 11,028 & 6,799 & 17,897 \\
\hline
\end{tabular}

Remarks: $\mathrm{B} 3=\mathrm{B}$ and 3; $\mathrm{B} 4=\mathrm{B}$ and $4 ; \mathrm{B} 6=\mathrm{Band} 6 ; \mathrm{B} 7=$ Band 7

Based on the MLR analysis model by Equation [3], the estimated distribution of SOM is presented in Figure 1 and Table 6. The estimated SOM content (Table 6) ranged from very low $(<1 \%)$ to moderate $(2.1-4.2 \%)$, and the largest area $(11,028$ ha) showed low (1$2 \%)$. Figure 1 clearly shows that SOM with low-level content area dominates throughout the study area, while areas with moderate level SOM content are seen to spread, and very low-level SOM content areas are hardly visible on the map due to the very small extent.

\section{DISCUSSION}

This study was demonstrated that the SOM content in Sukoharjo Regency can be estimated by the DN value of Landsat $8 \mathrm{OLI}$ imagery and field data through MLR analysis in a moderate reliability fit model. The established MLR model determined is presented as Equation [3], produced a similar result to Sukojo \& Wahono (2002) were conducted in South Malang using all bands in Landsat 7 ETM Imagery to estimating SOM by MLR analysis. Another study by Kongapai (2007) in Nakhonpratom Province, Thailand, also found that the ability of several Landsat 7 ETM imagery bands (Band 1, 3, and 4) to estimating the SOM using MLR analysis.

The value of $R^{2}$ of the best model (Band 3, 4, 6, and 7) was 0.399 (Table 3), which indicated that the model can predict the SOM content with moderate accuracy (Ratner, 2009). The moderate-level of accuracy might have resulted from the ability of Landsat Imagery in predicting the SOM content. As stated by Shonk et al. (1991), the ability of satellite imagery to examine soil properties based on spectral reflectance is strongly influenced by several factors including soil moisture, soil texture, soil organic matter, mineral composition, and the inclination angle of satellite sensors. Wu et al. (2009) added that a variety of parent material and vegetation cover in the research area also influence the appearance of errors in the estimation results. The condition of the research area which is very diverse in terms of soil types, vegetation, cultivation systems, and a very large observation area might result in a decrease in the accuracy of the model in estimating SOM. Moreover, Landsat 8 OLI Imagery only has $30 \mathrm{~m}^{2}$ spatial resolution that 
classified as a moderate scale, which also contributes to the decreased value of the accuracy, even though it is still acceptable for measuring SOM distribution on a regional scale.

The results of the SOM distribution based on the MLR model indicated that the paddy field area at Sukoharjo Regency was placed dominantly on land with low-level SOM (Table 6) and exist in all research area as shown in Figure 1. The combination of Band 3, 4,6 , and 7 of Landsat 8 OLI Imagery produced the best MLR models for predicting the SOM content. This is compatible with the previous research from Summers et al. (2011) who stated that the SOM content can be easily identified through the wavelength of the visible light spectrum (Band 2-4) using a soil color approach. Several literatures also stated that Short-wave InfraRed (SWIR) wavelengths (Band 6-7) are commonly used to estimate the SOM content of less than $2 \%$ (very lowlevel and low-level) to avoid confusion of soil color caused by soil moisture (Nocita et al., 2013; Stephens et al., 2004). The SWIR wavelength spectrum $(1.4-2.5 \mu \mathrm{m})$ is more sensitive to soil moisture; thus it is more widely used in organic material estimation (Nocita et al., 2013). Band 2 was not included as a significant variable in the estimation model because according to the results of the best subset analysis (Table 3 ) the Band 2 variable reduces the level of accuracy (adjusted $\mathrm{R}^{2}$ ) from the estimation results. According to (Department of the Interior USGS, 2015) Band 2 of Landsat 8 OLI Imagery is mainly used for water surface observation and not intended for advanced soil observation.

Each DN value of a Landsat image basically has the potential to be used as a SOM estimation model using the SLR analysis as presented in Table 2. However, each SLR model was produced different variations in the distribution area of SOM (Table 5). The result is indicating the difference of each band in estimating the SOM content because the sensors of Landsat satellite have different sensitivity to brightness level and reflectance from an object on the surface of the earth. Light soil color (high brightness in the image) indicates the low SOM content, whereas dark soil color (low brightness in the image) indicates the high SOM content (Chen et al., 2000). The model of MLR analysis to estimates SOM content was carried out to obtaining a combination of the Landsat 8 bands. So, the model can estimate SOM more accurately and eliminate the shortcomings of the SLR model. Ahmed \& Iqbal (2014) revealed that a various range of wavelength spectrum is needed to access the soil properties characteristics. Daendoro (2012) reported that Landsat 8 OLI Imagery is multispectral imagery with several bands, and each band is complementary in providing information.

Although our model from the MLR analysis can perform estimating the SOM content in Sukoharjo Regency, it might not be practical because Landsat Imagery is not a high-resolution imagery (30-m resolution); thus it is very difficult to visualize the SOM distribution in detail as in Indonesia the average of the farmers only own $250 \mathrm{~m}^{2}$ paddy field area. We might be able to detect withinfield spatial variability in the SOM content by using high-resolution imageries including PlanetScope (3-m resolution) and SkySat (0.72-m resolution). However, attention should be paid to the estimation accuracy because of the differences in the available bands. Therefore, there must be further research on the estimation model constructed from high-resolution imageries whether they are suitable if applied at a different place and time from the time of observation. 


\section{CONCLUSION}

The SOM distribution in the paddy field of Sukoharjo Regency, Indonesia, can be estimated using the combination of bands 3 , 4, 6, and 7 from Landsat 8 imagery through Multiple Linear Regression analysis. The estimated SOM content ranged from very low $(<1 \%)$ to moderate $(2.1-4.2 \%)$, and the largest area $(11,028 \mathrm{ha})$ showed low (1-2\%). These results of the research might be useful for enhancing precision agriculture farming systems and assist other scientists with a basic method that could be improved to get more better results.

\section{REFERENCES}

Agus, F. (2011). Environmental and sustainability issues of Indonesian agriculture. J Litbang Pert, 30(4), 140147.

Ahmed, Z., \& Iqbal, J. (2014). Evaluation of Landsat TM5 Multispectral Data for Automated Mapping of Surface Soil Texture and Organic Matter in GIS. European Journal of Remote Sensing, 47(1), 557-573. https://doi.org/10.5721/eujrs20144731

Al-doski, J., Mansor, S. B., \& Shafri, H. Z. M. (2013). Support vector machine classification to detect land cover changes in Halabja City, Iraq. IEEE Business Engineering and Industrial Applications Colloquium (BEIAC), 353358.

https://doi.org/10.1109/BEIAC.2013.656 0147

Balai Penelitian Tanah. (2005). Analisis Kimia Tanah, tanaman, air, dan pupuk: Petunjuk Teknis (B. H. Prasetyo, D. Santoso, \& R. W. Ladiyani, Eds.). Bogor, Indonesia: BALAI PENELITIAN TANAH.

BPS Statistic of Sukoharjo Regency. (2015). Kabupaten Sukoharjo dalam angka 2015. Sukoharjo, Indonesia: Penerbit BPS.

Chen, F., Kissel, D. E., West, L. T., \& Adkins, W. (2000). Field-scale Mapping of Surface Soil Organic Carbon using Remotely Sensed Imagery. Soil Sci. Soc. Am. J.,
64(2),

$746-753$.

https://doi.org/10.2136/sssaj2000.64274

$6 \mathrm{x}$

Daendoro, P. (2012). Pengantar penginderaan jauh digital. Yogyakarta, Indonesia: Penerbit Andi.

Deng, Y., Wu, C., Li, M., \& Chen, R. (2015). RNDSI: A ratio normalized difference soil index for remote sensing of urban/suburban environments. International Journal of Applied Earth Observation and Geoinformation, 39, 40-48.

https://doi.org/10.1016/j.jag.2015.02.01 0

Department of the Interior USGS. (2015). Landsat 8 (L8) Data Users Handbook. Sioux Falls, South Dakota: U.S. Geological Survey.

Gatu, C., \& Kontoghiorghes, E. J. (2006). Branch-and-Bound Algorithms for Computing the Best- Subset Regression Models. Journal of Computational and Graphical Statistics, 15(1), 139-156. https://doi.org/10.1198/106186006X100 290

Hutchinson, J. J., Campbell, C. A., \& Desjardins, R. L. (2007). Some perspectives on carbon sequestration in agriculture. Agri. Forest Meteorol., 142(2-4), 288-302. https://doi.org/https://doi.org/10.1016/j .agrformet.2006.03.030

Idris, M., Subiyanto, S., \& Sabri, L. (2014). Analisis pemanfaatan citra Landsat 7 untuk pemetaan kandungan bahan organik tanah dengan metode PCA dan regresi linier berganda bertahap di Kabupaten Bangkalan. J. Geodesi Undip, 3(1), 51-64.

Kim, H. J., Sudduth, K. A., \& Hummel, J. W. (2009). Soil macronutrient sensing for precision agriculture. Journal of Environmental Monitoring. Journal of Environmental Monitoring, 11(10), 18101824. https://doi.org/10.1039/b906634a

Komatsuzaki, M., \& Ohta, H. (2007). Soil management practice for sustainable agroecosystem. Sustainability Science, 2(1), 103-120. https://doi.org/10.1007/s11625-006- 
0014-5

Komatsuzaki, M., \& Syuaib, M. F. (2010). Comparison of the Farming System and Carbon Sequestration between Conventional and Organic Rice Production in West Java, Indonesia. Sustainability Science, 2, 833-843. https://doi.org/https://doi.org/10.3390/ su2030833

Kongapai, P. (2007). Application of remote sensing and geographic information system for estimation of soil organic matter in Nakhonpratom Province. Mahidol University, Thailand.

Lee, S. B., Lee, C. H., Jung, K. Y., Park, K. Do, Lee, D., \& Kim, P. J. (2009). Changes of soil organic carbon and its fractions in relation to soil physical properties in a long-term fertilized paddy. Soil \& Tillage Research, 104, 227-232. https://doi.org/https://doi.org/10.1016/j .still.2009.02.007

Nocita, M., Stevens, A., Noon, C., \& Wesemael, B. van. (2013). Prediction of soil organic carbon for different levels of soil moisture using Vis-NIR spectroscopy. Geoderma, 199, 37-42. https://doi.org/10.1016/j.geoderma.201 2.07.020

Rahmati, M., Oskouei, M. M., Neyshabouri, M. R., \& Fard, A. (2016). Soil Organic Carbon Prediction using Remotely Sensed Data at Lighvan Watershed, Northwest of Iran. Azarian Journal of Agriculture, 3, 45-49.

Ratner, B. J. (2009). The correlation coefficient: Its values range between $+1 /-1$, or do they? Target Meas Anal Mark, 17(2), 139-142. https://doi.org/https://doi.org/10.1057/j t.2009.5

Shonk, J. L., Gaultney, L. D., Schulze, D. G., \& Scoyoc, G. E. Van. (1991). Spectroscopic Sensing of Soil Organic Matter Content. Transactions of the ASAE, 34(5), 19781984.

https://doi.org/10.13031/2013.31826
Singh, S. K., Srivastava, P. K., \& Gupta, M. (2014). Appraisal of land use/land cover of mangrove forest ecosystem using support vector machine. Environ Earth Sci, 71(5), 2245-2255. https://doi.org/https://doi.org/10.1007/ s12665-013-2628-0

Stephens, S. C., Rasmussen, V. P., Ramsey, R. D., Whitesides, R. E., Searle, G. S., \& Robert, L. (2004). Remote Sensing Organic Carbon in Soil. Utah, US: Utah State University.

Sukojo, B. ., \& Wahono. (2002). Pemanfaatan Teknologi Penginderaan Jauh untuk Pemetaan Kandungan Bahan Organik Tanah. J. Makara Teknologi, 6(3), 102112.

Summers, D., Lewis, M., Ostendorf, B., \& Chittleborough, D. (2011). Visible nearinfrared reflectance spectroscopy as a predictive indicator of soil properties. Ecological Indicators, 11(1), 123-131. https://doi.org/10.1016/j.ecolind.2009.0 5.001

Sunaryo, S., \& Siagian, T. . (2011). Mengatasi masalah multikolinearitas dan outlier dengan pendekatan robpca (studi kasus analisis regresi angka kematian bayi di Jawa Timur). J. Matematika, Saint, Dan Teknologi, 12(1), 1-10.

Supriyadi, Sudaryanto, R., Purwanto, \& Hartati, S. (2014). Kualitas tanah, menuju pertanian yang berkelanjutan. Surakarta, Indonesia: Yuma Pressindo.

Syuaib, M. F. (2016). Sustainable agriculture in Indonesia: Facts and challenges to keep growing in harmony with environment. Agricultural Engineering International: CIGR Journal, 18(2), 170-184.

Wu, C., Wu, J., Luo, Y., Zhang, L., \& DeGloria, S. D. (2009). Spatial Prediction of Soil Organic Matter Content Using Cokriging with Remotely Sensed Data. Soil Sci. Soc. Am. J., 73(4), 1202-1208. https://doi.org/10.2136/sssaj2008.0045 